\title{
DMin as Practical Theology
}

\author{
Stuart Blythe
}

check for

updates

Citation: Blythe, Stuart. 2021. DMin as Practical Theology. Religions 12: 31 https://doi.org/10.3390/rel12010031

Received: 6 December 2020 Accepted: 30 December 2020 Published: 4 January 2021

Publisher's Note: MDPI stays neutral with regard to jurisdictional clai$\mathrm{ms}$ in published maps and institutional affiliations.

Copyright: (C) 2021 by the author. Licensee MDPI, Basel, Switzerland. This article is an open access article distributed under the terms and conditions of the Creative Commons Attribution (CC BY) license (https:// creativecommons.org/licenses/by/ $4.0 /)$.
Acadia Divinity College, Wolfville, NS B4P 2R6, Canada; stuart.blythe@acadiau.ca

Abstract: The Doctor of Ministry is a professional degree accredited by the Association of Theological Schools. As delineated by ATS, the theological program requires to meet specific learning outcomes in a minimum of 30 credit hours with a culminating project that contributes to the understanding of ministry practice. Practical theology is a discipline that seeks to take "both practice and theology seriously". As a consequence, the DMin can be generally conceptualized as practical theology. However, this paper demonstrates a number of the specific ways in which this general claim can be substantiated. It does this with reference to a number of theoretical discussions within practical theology as to the discipline's nature. It then examines the implication of this for the status of the DMin, student learning, program design, and the nature of the DMin project.

Keywords: practical theology; Doctor of Ministry; theological education; program design; student learning

\section{Introduction}

The Doctor of Ministry (DMin) is a professional degree accredited by the Association of Theological Schools (ATS). This article describes the DMin program and the discipline of practical theology. It argues that the DMin can be explicitly conceptualized as an expression of practical theology. It does this with reference to a number of theoretical discussions about the nature of practical theology. It then highlights four implications of conceptualizing the DMin program in this way. These implications relate to the status of the program, student learning, program design, and the nature of the project.

\section{DMin}

In the USA and Canada, the Doctor of Ministry Degree is an "advanced, professionally oriented degree" with accreditation standards established by ATS (ATS Standards 2020, p. 7). In 2020, according to the Association for Doctor of Ministry Education (ADME 2020) website, 156 ATS schools offered DMin programs (2020). The original DMin standards were authorized in 1970, revised in 1984, 1996, and most recently in June 2020 (ADME 2020). These standards deal with "principles of quality". They enable the ATS Commission to fulfill its purpose "to contribute to the enhancement and improvement of theological education through the accreditation of schools" (ATS Standards 2020, pp. ii-iii).

The DMin, therefore, is a program of theological education. The standards establish agreed parameters, defining the nature of this education. Standard 5:3 is one of the most significant in defining the outcomes and hence the nature of the DMin. It states that a DMin program should have:

clearly articulated student learning outcomes that are consistent with the school's mission and resources and address the following four areas: (a) advanced theological integration that helps graduates effectively engage their cultural context with theological acumen and critical thinking; (b) in-depth contextual competency that gives graduates the ability to identify, frame, and respond to crucial ministry issues; (c) leadership capacity that equips graduates to enhance their effectiveness as ministry leaders in their chosen settings; and (d) personal and spiritual matu- 
rity that enables graduates to reinvigorate and deepen their vocational calling. (ATS Standards 2020, p. 7)

The standards also state that graduates should successfully complete a "minimum of 30 semester credits or equivalent units" and that,

The Doctor of Ministry degree provides a variety of student learning and formational experiences that include peer learning, self-directed learning, researchbased learning, and field-based learning. The degree culminates with a written project that explores an area of ministry related to the student's vocational calling, utilizes appropriate research methodologies and resources, and generates new knowledge regarding the practice of ministry. (ATS Standards 2020, p. 7)

The standards, therefore, specify the nature of the DMin in terms of learning areas, credit hours, the type of learning experiences, and the necessity for a culminating project.

These standards define the parameters of DMin. However, they are standards "that all schools meet in various ways" (ATS Standards 2020, p. iii). Schools have contextual flexibility regarding their programs' precise structure in keeping with their theological commitments, resources, and mission goals. Across the schools, therefore, there is less uniformity than the term standard may imply. Data published by ATS in February 2020 indicated the considerable variation by different schools in terms of the credit hours expected and the weighting given to the DMin project (Tanner 2020, p. 1). The revised standards introduced a stated "minimum" of credit hours while maintaining the possibility of contextual interpretation in many other areas. Consequently, there continues to be variety in terms of content, structure, length, and the weighting given to the project. However, despite such variety, it is an identifiable theological education program at an advanced level that focuses on professional ministry practice through both taught and research components.

\section{Practical Theology}

The emergence of practical theology is frequently attributed to the work of Friedrich Schleiermacher (1768-1834). Christian Grethlein helpfully demonstrates that this emergence and later developments in practical theology in Germany and, in turn, the USA resulted from specific social and cultural changes and challenges to the life of the Christian Church (Grethlein 2016, pp. 1-59). In the USA, the contemporary turn in the discipline is associated with the pastoral theology of A. T. Boisen (1876-1965) and Seward Hiltner (1909_ 1984) (Aden and Ellens 1990). The "profile" was then subsequently developed, not least by Don Browning (1934-2010) and Richard Osmer (b. 1950) (Grethlein 2016, pp. 49-58).

Various definitions or better descriptions of practical theology proliferate. Historical, geographical, and theological commitments inform these descriptions. Further, the focus on practice creates endless contexts that push back into the discipline and how it is understood and carried out. This sort of reflexivity produces ongoing conversations about the nature of the discipline. These include discussions about practical theology's relationship to the church, other theological disciplines, different sources of knowledge, and its commitment to social scientific methodologies and methods. Such issues can be embraced at a theoretical level as a sign of health and vitality in an established but yet-developing discipline. On the other hand, such theoretical complexity may confuse or daunt some of the wouldbe practitioners, such as the "religious leaders" and "teachers and students" which the academic reflection aims to serve (Miller-McLemore 2012, p. 20).

Be the above as it may, many theoreticians of practical theology are also theological educators. Their theoretical reflections provide not merely "conundrums" (Mercer and Miller-McLemore 2016) but valuable perspectives for delineating the discipline. I will draw upon some of these perspectives in discussing the DMin as practical theology. The choices I make will reflect my position on several issues. Therefore, I will be "forthright" on some of the factors that inform my perspective (Osmer 2012, p. 67). I am a Scottish born and British educated Christian practical theologian. I currently teach in the area of homiletics and direct the doctoral program at a Canadian school. This school, Acadia Divinity College 
(ADC), states that its mission is to "equip Christian leaders for full-time and volunteer ministry in Canada and the world" (ADC 2020-2021, p. 7).

Following on from the above, I will draw specifically, though not exclusively, on three sources concerning the nature of practical theology. The first is the published version of the presidential address given by Bonnie J. Miller-McLemore at the International Academy of Practical Theology, 25 July 2011 (Miller-McLemore 2012). In this address, she highlights and contributes to a number of discussions about the nature of practical theology. Second, Richard R. Osmer's response to that address (Osmer 2012). Both of these articles place the discussion within a North American context. Third, Pete Ward's Introducing Practical Theology: Mission, Ministry, and the Life of the Church (Ward 2017). This book is significant for several reasons. Ward's book expands upon some of the ideas he presented as a response to Miller-McLemore's address (Ward 2012). He builds positively on Miller-McLemore's understanding that practical theology operates in four "enterprises" (Ward 2017, pp. 10-11). He offers something of the theological hospitality that Osmer calls for in his response to Miller-McLemore. That is, Ward seeks to mediate between more "conservative" and more "liberal" approaches to the relationship between experience and doctrine (Ward 2017, p. 5). In addition, Ward very clearly locates his own approach to practical theology in the ministry and mission of the Christian Church. This is not to deny that "practical theology is and can be done by those with a wide variety of faith backgrounds and none" (Ward 2017, p. 3). It is, however, to place it within a Christian ecclesial framework "in the church and in the world" (Ward 2017, p. 2). This is also my own approach.

\section{DMin as an Expression of Practical Theology}

In general terms, Ward describes practical theology as "any way of thinking that takes both practice and theology seriously" (p. 5). The DMin, as described by ATS, is a professional program which, through its focus, learning outcomes, learning and teaching strategies, and culminating project, reflects this way of thinking. While some schools refer to practical theology in their descriptions of their DMin, ATS does not. To be sure, it is not a program "in" practical theology, in the sense that its primary focus is the academic study of the discipline. Instead, the DMin seeks to enable students to address the "cultural context" and "ministry situation" in which they are leaders through the means and methods of practical theology. As such, therefore, it can be conceptualized as an expression of practical theology.

The work of Miller-McLemore, however, helps brings greater nuance to describing the DMin program as practical theology. Thus, she argues in contrast to those who claim that practical theology is either "un-definable" or "easily defined" that practical theology is a "complex" and "multivalent" term with four "distinctive" and yet "connected and interdependent" uses (Miller-McLemore 2012, pp. 18-23). She describes these as follows:

an activity of believers seeking to sustain a life of reflective faith in the everyday, a method or way of analyzing theology in practice used by religious leaders and by teachers and students across the theological curriculum, a curricular area in theological education focused on ministerial practice and subspecialties, and, finally, an academic discipline pursued by a smaller subset of scholars to support and sustain these first three enterprises. (Miller-McLemore 2012, p. 20). ${ }^{1}$

In terms of this description, the DMin corresponds primarily to the third and second uses. The DMin program is a curricular area of theological education concerned with the practice of religious leaders. It also actively draws upon practical theology methods in its learning and teaching approaches.

Its contextual nature further supports the DMin program's conceptualization as an expression of practical theology. Context plays a significant role in practical theology at a variety of levels. Grethlein highlights the significance of contextual and cultural factors,

1 The four expressions of practical theology, which McLemore identifies in this address also determine the structure of The Wiley-Blackwell Companion to Practical Theology, of which she was the editor (Miller-McLemore 2012, p. 19). 
shaping practical theology's development at historical and national levels (Grethlein 2016). Osmer reinforces the significance of contextual factors concerning the development of different "genres" of theology, including practical theology (Osmer 2012, pp. 75-77). MillerMcLemore, drawing on the work of Bent Flyvbjerg, discusses the nature and significance of "context dependent" knowledge, such as is gained through practical theology, not least for higher levels of learning (Miller-McLemore 2012, pp. 10-13). Ward, referring to the view that all theology is contextual, relates contextual theology to local theology, and again back to the life and activity of specific communities of practice (Ward 2017, pp. 137-39). One could summarize that attention to contextuality is a critical feature of anything that would wish to claim that it was practical theology. The DMin stresses such contextuality in relation to the specific ministry and vocational concerns of its students. Further, the ATS standards explicitly state that one of the areas the learning outcomes of all DMin programs need to address is "in-depth contextual competency" (ATS Standards 2020, p. 7).

Its constructive concerns also advance the DMin's conceptualization as an expression of practical theology. Miller-McLemore argues that practical theology is not merely a descriptive practice of analysis but a constructive practice. Indeed, she asserts, "Many would argue that practical theology is, in fact, not complete without a move from description to normative construction and action" (Miller-McLemore 2012, p. 25). Osmer strongly agrees, stating,

As a form of theology, it is not enough for practical theology to serve as little more than "social science lite," resting content with empirical, descriptive, and interpretive approaches to its subject matter. (Osmer 2012, p. 70)

Osmer also agrees with Miller-McLemore that practical theology's current expressions need to do a better job of articulating and fulfilling its constructive potential (Osmer 2012, p. 71). The DMin aims at such constructive action and application. The goal is that students are not merely able to "identify" and "frame" ministry issues but "respond" to them. Furthermore, the program aims at this sort of constructive outcome while also enhancing the skills and deepening the spiritual maturity of these religious leaders. (ATS Standards 2020, p. 7). So understood, the DMin is a constructive expression of practical theology, of which the project at least should be an example.

The ministry experience of the students who take the DMin program is also a factor in its constructive potential as an expression of practical theology. Ward writes,

Practical theology is one of the ways that practitioners can look up from where their professional ministry has taken them and find ways to reorient themselves. This might take the form of finding new ways to think about God and the practice of ministry, or it may simply mean finding ways to connect absorbed theology and the tradition of the church to new forms of practice and professional life. (Ward 2017, p. 23)

The sort of reorientation that Ward discusses assumes prior and present ministry experience. The DMin is specifically for people who already have ministry experience and not merely seeking it. The ATS Standards state, "The Doctor of Ministry degree is an advanced professional doctorate that builds upon an accredited master's degree in a ministry-related area and upon significant ministry experience" (ATS Standards 2020, p. 7). In turn, the program is designed to be taken part-time and in situ. The practitioner's ministry situation is to be the locus of their studies. The program is concerned not merely with theological learning but theological reorientation to new forms of understanding and practice in the lives of experienced ministry practitioners.

The above discussion supports the conceptualization of the DMin as an expression of practical theology. However, this emphasis on the education of ministry leaders, could be seen as a negative return to the "clerical paradigm" in practical theology. As discussed by Miller-McLemore, the clerical paradigm refers to the idea that clergy or leaders' theological education involved providing bits of help and hints for ministry practice (Miller-McLemore 2012, p. 13). This perception has led to a disdain for and distancing from ministerial 
education as the focus for practical theology (Miller-McLemore 2007, pp. 19-20). MillerMcLemore directly addresses this situation, writing that "The clerical paradigm is a poor diagnosis for all that ails theological education" (Miller-McLemore 2012, p. 13). In contrast, she suggests that the problem has been the "academic paradigm." By this, she means an overemphasis on "cognitive intelligence" (p. 14). Thus, she maintains that, while "mental intelligence is important", it is "not sufficient" (p. 14). Consequently, practical theology also needs to give attention to the sort of practical "wisdom" that those in ministry need and the application of such in practice (pp. 14-15). Therefore, to focus on religious leaders' theological education in practical theology need not signal a naïve return to the "clerical paradigm." It can rather indicate the willingness to grapple with the range of types of knowledge involved and necessary in the theological study of practice. ${ }^{2}$

Moreover, it can be argued that the education of religious leaders, such as in the DMin, has both a mediating and generative role in the discipline of practical theology. The religious leaders experience the academy through their courses. These religious leaders, however, through their ministry situations, connect with the lives of every-day believers seeking to live out their faith in practice. In turn, the leaders bring their communities' real concerns back into the classroom and, consequently, back into the academy. ${ }^{3}$ Therefore, disregarding the clerical paradigm is to risk uprooting practical theology from "the everyday practices of the Christian faith in the church and in the world" (Ward 2017, p. 2). Practical theology as a discipline emerged out of the theological education of ministers (Ward 2017, p. 70). Therefore, it should not be surprising that it can have a mediating and generative role for the discipline.

The above discussion claims the DMin is a theological education program that focuses on practical ministry issues, contextual concerns, constructive goals, experienced religious leaders, and a broad understanding of the nature of knowledge. As such, it can be conceptualized as an expression of practical theology in relation to a number of discussions about the nature of the discipline. I will now discuss four implications of this understanding.

\section{The Status of the DMin Program}

Conceptualizing the DMin program as practical theology positively situates it in theological education's formal culture. It does this within an academic culture which, as discussed above, has at times devalued the study of the practice through an emphasis on "cognitive intelligence" (Miller-McLemore 2012, p. 14). Miller-McLemore argues that academic culture and contemporary education have increasingly recognized the importance of practice related knowledge (pp. 7-13). Ward makes a complimentary point, "In recent years there has been a move towards practice that is evident across a range of disciplines within the study of religion and theology" (Ward 2017, p. 120). This move highlights the significance of practical theology's particular concerns with practice (Miller-McLemore 2012, pp. 12-13). It is also a move that helps negate some traditional and, at times, hierarchical distinctions in theological education concerning courses and programs concerned with practice. These are the distinctions made between academic and practical, or better, between theoretical and practical courses. Browning claims that all practices are "meaningful or theory-laden" (Browning 1991, p. 6). Insofar as this is the case, then the idea that the study of practice is somehow not theoretical or the theoretical not somehow practical falls. As a consequence, practical theology sits more squarely as an equal partner among the other traditional disciplines. Consequently, the DMin as practical theology has a more evident status as a significant theological education program in its own right, dealing with a particular kind of contextual and constructive knowledge.

2 Miller-McLemore develops this emphasis on the necessity for practical wisdom and other forms of practical knowledge in her later writings, including her essay "The Theory-Practice Binary and the Politics of Practical Knowledge" in the previously mentioned book, Conundrums in Practical Theology, (Miller-McLemore 2016, pp. 190-218).

3 This discussion does not foreclose the idea that theological educators may also be religious leaders in ministry situations or that members of the congregation may take theological studies. The latter, however, is unlikely in the DMin, given its professional nature. 


\section{Student Learning}

The second implication of explicitly conceptualizing the DMin as practical theology is that it helps frame student learning. DMin programs are a mixture of taught courses and a project. To locate the DMin in the discipline of practical theology introduces students to the dynamic of an integrating discipline for what they are doing. From the perspective of this discipline, they can critically reflect not only upon what they are learning but the process of learning. In this process, they encounter the types of knowledge that are being generated and evaluated. They do this not merely in the abstract but while actively engaged with issues of concrete situational relevance to them and their ministry. The DMin program does not require students to take any fixed particular stand on the relative weight given to these different knowledge sources. Nor should it. A hospitable practice of practical theology needs to be open to various perspectives on how knowledge generated from Scripture, reason, tradition, and experience interacts. Nevertheless, the DMin as practical theology introduces students to these various sources of knowledge and gives them a frame, such as with the "Wesleyan quadrilateral" (Osmer 2012, pp. 74-75), by which they can explicitly reflect upon their thinking.

\section{Program Design}

To conceptualize the DMin program as practical theology also has implications for program design. The ATS standards require all DMin programs to reflect a certain kind of learning outcome. As discussed above, this is learning that takes both practice and theology seriously. Therefore, the critical issue is how a program's design integrates the student, the communities to which they belong, the different sources of knowledge encountered and indeed the curriculum's various courses. According to Kathleen A. Cahalan, such integration in theological education "is often regarded as the pressing problem of the day," but is also one to which "minimal scholarship" has been directed (Cahalan 2012, p. 387). As a consequence, she suggests ways in which practical theology can pay greater attention to integration through theological education (pp. 388-94). This concern for integration in theological education is one to which those who design DMin programs should pay attention.

One strategy for integration in DMin program design is based on content. For example, a DMin that focuses on preaching may have some general research courses, with most courses exploring varying aspects of preaching and culminating in a preaching research project. The primary unifying factor is content.

An alternative approach to program design, however, which seeks integration at the level of knowledge generated, evaluated, and practiced, is constructive alignment (Biggs 2014). ${ }^{4}$ This approach to program design begins with the learning outcomes of the program. The various courses are then designed and delivered to enable these learning outcomes to be achieved. In this model, the integration of the courses and the program does not take place primarily at the level of content. Instead, the integration occurs at the level of intended learning expressed through demonstrable understanding, skill, and personal qualities.

The DMin program of my school is built on this model. In this program, all students typically take two courses in the Bible, theology, ministry practice, and courses that require personal self-reflection, in addition to courses that prepare specifically for the research project. These courses vary in content. However, they integrate through the program's learning outcomes, which are designed to produce certain types of demonstrable knowledge, skills, and qualities in relation to practice. To illustrate, the DMin program at ADC has the following learning outcomes directly influenced by the ATS Standards: ${ }^{5}$

4 A learning outcomes model of program design through constructive alignment is common in Higher Education in the UK and is increasingly common in Canada.

5 These learning outcomes were intentionally designed to map to the description of the DMin published in the Degree Program Standards approved in 2012 and posted in 2015 (ATS 2015). They remain consistent with the expectations of the new standards (ATS Standards 2020). 
By the end of this program, participants should be able to:

1. Critically discuss and research advanced biblical and theological understandings pertinent to developing enhanced ministry practice.

2. Show an advanced contextually and culturally aware understanding and integration of ministry in which theory and practice interactively inform each other.

3. Demonstrate skills and abilities, including methods of appropriate research, that enable effective ministry leadership at a high level.

4. Critically reflect upon various personal, professional, vocational, and spiritual, values, attitudes, emotions, and competencies, as witness to maturing faith.

5. Contribute to the understanding and practice of ministry through the completion of a doctoral level thesis/project that contributes new knowledge and understanding to the practice of ministry.

It should be apparent from the above how these learning outcomes seek to explicitly facilitate the sort of integrated learning required by ATS and which can be described as an expression of practical theology.

These program learning outcomes, however, are only part of the story. Each course in the program also has its own learning outcomes that demonstrate how it contributes to the program learning outcomes. The point is not that every course meets all the learning outcomes of the program. Instead, the goal is that the program's learning outcomes are met through all the courses' cumulative learning.

The above does not mean that the particular content of each course is not important. Indeed, two learning outcomes from each course will require the demonstration of contentspecific knowledge. Be this as it may, the learning outcomes of each course go beyond the specifics of the content towards the transferable learning that will enable students to achieve the program's learning outcomes.

This approach to program design also has consequences for delivery. In constructive alignment, the learning and teaching strategies and the assessments should be explicitly directed towards facilitating each course's learning outcomes and those of the program as a whole. The ATS standards call for a variety of appropriate learning and teaching strategies including, "formational experiences that include peer learning, self-directed learning, research-based learning, and field-based learning" (ATS Standards 2020, p. 7). These strategies accord with the learning and teaching strategies favored in practical theology to situate, generate, evaluate, and develop the sort of knowledge and practice central to the discipline. See, for example, Emily Click's discussion on "field-education" as "Contextual Education" (Click 2012, pp. 347-56). Therefore, to describe the DMin as practical theology invites thoughtful consideration of how best to facilitate the learning that the course and program intends to achieve. Since this learning involves not merely the capacity to "think theologically" but to "practice theology," teaching practical theology is complicated and requires attention to a large number of factors (Miller-McLemore 2008, p. 173).

The need to design and reflect upon the learning and teaching strategies for teaching in a program concerned with facilitating a particular form of integrated learning is continual. It has extra intensity when and where such teaching and learning occurs online or in hybrid models, whether adopted by choice or necessity. However, constructive alignment is one way to explicitly seek to facilitate the sort of process that enables the type of integration, which Cahalan argues is important in practical theological education (Cahalan 2012).

\section{The DMin Research Project}

A fourth area where conceptualizing the DMin project as practical theology can have implications is regarding the nature of the DMin research project. Schools vary in the weighting which they give to this project. Since the ATS Standards (2020) suggest that it is the "culmination" of the program, one would expect the project to build upon prior learning concerning content and thinking takes practice and theology seriously. Explicitly approaching the DMin project in this way can open up rather than restrict the nature of such projects. 
Tim Sensing's book, Qualitative Research: A Multi-Methods Approach to Projects for Doctor of Ministry Theses (Sensing 2011), is one of the few published books that deal specifically with DMin projects. Sensing is critical of the quality of many DMin projects. He sees the correlative value of different sources of knowledge as dialogical and transformative (p. xvi). Therefore, he aims to introduce qualitative methods that will enable research into ministry situations to be carried out according to high academic standards (pp. xiii-xxxiii). This emphasis on the quality of empirical research rightly highlights the significance of practice in practical theology. Moreover, it builds upon the idea that practical theology begins with "human experience" (p. xv) or, as classically articulated by Browning, that practical theology moves from "practice to theory and back to practice" (Browning 1991, p. 7). This is a very helpful approach. It offers good guidance for the structure and shape that many DMin projects will take.

However, there are also other possible approaches to DMin projects as practical theology, which do not need to major significantly on empirical research. Practical theology takes both practice and theology seriously. Yet, the relationship between the sources and nature of related knowledge derived from theology and practice is not straightforward. The sources and nature of such knowledge are always implicated with one another. People who claim that they are starting from experience already understand that experience through Scripture and tradition. Those who claim that they are starting with Scripture bring interpretations shaped by experience and tradition. (Ward 2017, pp. 3-4). In turn, as Osmer argues, while making a case for a more ecumenical and pluralistic approach to practical theology, people from different traditions and contexts give different "epistemic weight" to various sources of knowledge (Osmer 2012, pp. 73-75). This has methodological implications for research in practical theology. It opens up a variety of valid methodological approaches including those which might be described as "applied" approaches (Ward 2017, pp. 3-6).

Perhaps a shift in language can help provide a constructive proposal regarding other methodological approaches. Both practical theology and the DMin project focus on practice. It is this focus on practice that helps make practical theology practical. The DMin project is required to generate "new knowledge regarding the practice of ministry" (ATS Standards 2020, p. 7). However, none of this precludes various "entry points" for stimulating the dialogical interaction between theology and practice. Practice can be approached and explored from the entry point of biblical studies, or systematic theology, or Christian ethics, or church history, as well as from the empirically descriptive nature of practice itself. Indeed, this may be to recognize and develop its claimed interdisciplinary nature (Osmer 2012, p. 72). As a consequence, DMin projects should be capable of a variety of shapes and structures, as determined by the context. They need not major on the descriptive. The question is not whether a project as practical theology includes empirical research, but whether it takes both practice and theology seriously. To be sure, all DMin projects as practical theology will need to delineate the practice or, indeed, the conceptualization of the practice they wish to explore. However, how they delineate the practice and how they enter the project should be appropriate to the researcher, context, and issue, not predetermined. To borrow from Ward, this means paying attention to the "hermeneutical and epistemological significance of our students" (Ward 2012). To be sure, a project that approaches a particular practice from one entry point, say biblical studies, will be partial and limited. It may be more theoretical than descriptive. However, all approaches are partial and limited, and all can be equally valid if they help students take both practice and theology seriously in context and in a constructive way.

\section{Conclusions}

The professional DMin program in theological education can be explicitly conceptualized as an exercise in practical theology. In general terms it is a program that seeks to take both practice and theology seriously. More specifically, the program's focus, contextual nature, constructive goals, the nature of the students as religious leaders, and its methods, 
locate it within the discipline of practical theology. This is demonstrated with reference to theoretical discussions concerning the nature of practical theology. Further, and at a deeper level, this conceptualization forefronts the nature of the knowledge it generates, evaluates, and seeks to embody in constructive action. This has implications for the program in terms of its status, student learning, program design, and the format of DMin projects.

Funding: This research received no external funding.

Conflicts of Interest: The author declares no conflict of interest.

\section{References}

Acadia Divinity College. 2020-2021. Calendar. Available online: https:/ /acadiadiv.ca/academic-calendar / (accessed on 29 December 2020).

Aden, Leroy, and J. Harold Ellens, eds. 1990. Turning Points in Pastoral Care: The Legacy of Anton Boisen and Seward Hiltner. Grand Rapids: Baker Book House.

Association for Doctor of Ministry Education. Available online: https:/ / dmineducation.org/ (accessed on 6 December 2020).

Association of Theological Schools: The Commission on Accrediting. 2015. Degree Program Standards. Available online: https: //www.ats.edu/uploads/accrediting/documents/standards-of-accreditation-161130.pdf\#pagemode=bookmarks (accessed on 31 December 2020).

Association of Theological Schools: The Commission on Accrediting. 2020. Standards of Accreditation. Available online: https: //www.ats.edu/uploads/accrediting/documents/standards-of-accreditation.pdf (accessed on 6 December 2020).

Biggs, John. 2014. Constructive Alignment in University Teaching. ERDSA Review of Higher Education 1: 5-22. Available online: https:/ / www.herdsa.org.au/herdsa-review-higher-education-vol-1/5-22 (accessed on 6 December 2020).

Browning, Don S. 1991. A Fundamental Practical Theology: Descriptive and Strategic Proposals. Minneapolis: Fortress Press.

Cahalan, Kathleen A. 2012. Integration in Theological Education. In The Wiley-Blackwell Companion to Practical Theology. Edited by Bonnie J. Miller-McLemore. Chichester: Blackwell Publishing, pp. 386-95.

Click, Emily. 2012. Contextual Education. In The Wiley-Blackwell Companion to Practical Theology. Edited by Bonnie J. Miller-McLemore. Chichester: Blackwell Publishing, pp. 347-56.

Grethlein, Christian. 2016. An Introduction to Practical Theology: History, Theory, and the Communication of the Gospel in the Present. Translated by Uwe Rasch. Waco: Baylor University Press.

Mercer, Joyce Ann, and Bonnie Miller-McLemore, eds. 2016. Conundrums in Practical Theology. Leiden: Brill.

Miller-McLemore, Bonnie J. 2007. The "Clerical Paradigm": AFallacy of Misplaced Concreteness? International Journal of Practical Theology 11: 19-38. [CrossRef]

Miller-McLemore, Bonnie J. 2008. Practical Theology and Pedagogy: Embodying Theological Know-How. In For Life Abundant: Practical Theology, Theological Education, and Christian Ministry. Edited by Dorothy C. Bass and Craig Dykstra. Grand Rapids: William B. Eerdmans, pp. 170-90.

Miller-McLemore, Bonnie J. 2012. Five Misunderstandings About Practical Theology. International Journal of Practical Theology 16: 5-26. [CrossRef]

Miller-McLemore, Bonnie J. 2016. The Theory-Practice Binary and the Politics of Practical Knowledge. In Conundrums in Practical Theology. Edited by Joyce Anne Mercer and Bonnie Miller-McLemore. Leiden: Brill, pp. 190-218.

Osmer, Richard. 2012. Toward a New Story of Practical Theology. International Journal of Practical Theology 16: 66-78.

Sensing, Tim. 2011. Qualitative Research: A Multi-Methods Approach to Projects for Doctor of Ministry Theses. Eugene: Wipf and Stock.

Tanner, Tom. 2020. New Data to Consider on Duration of Doctor of Ministry Degree. Association of Theological Schools: The Commission on Accrediting. Colloquy Online February. Available online: https:/ / www.ats.edu/uploads/resources/publicationspresentations/colloquy-online/new-data-on-dmin-duration.pdf (accessed on 6 December 2020).

Ward, Pete. 2012. The Hermeneutical and Epistemological Significance of our Student. International Journal of Practical Theology 16: 55-65. [CrossRef]

Ward, Pete. 2017. Introducing Practical Theology: Mission, Ministry, and the Life of the Church. Grand Rapids: Baker Academic. 